\title{
Pesticide Susceptibility of Two Dominant Phytoseiid Mites, Neoseiulus californicus and $N$. womersleyi, in Conventional Japanese Fruit Orchards (Gamasina: Phytoseiidae)
}

\author{
Hiroshi AMANo*, Yuki ISHII and Youichi KobORI \\ Laboratory of Applied Entomology and Zoology, Faculty of Horticulture, Chiba University, Matsudo, \\ Chiba 271-8510, Japan
}

(Received 26 June 2003; Accepted 22 March 2004)

\begin{abstract}
Pesticide (six insecticides and 16 acaricides) susceptibility of populations of $N$. californicus (4 populations) and $N$. womersleyi (5 populations) was investigated to test the hypothesis that the recent species replacement between these two species was due to a change in pesticides used in orchards combined with a differential susceptibility of the two species to one or more of the new pesticides. Although the present results cannot provide a clear conclusion regarding factors responsible for the change in dominant phytoseiid, it was suggested, at this point, that none of the pesticides examined here seemed to have a decisive influence on the replacement of $N$. womersleyi by $N$. californicus.
\end{abstract}

Key words: Phytoseiidae, dominant species, pesticide susceptibility, geographical distribution, natural enemy, species displacement

\section{INTRODUCTION}

Two predacious phytoseiid mites Neoseiulus californicus (McGregor) and N. womersleyi (Schicha) show a good ability to act as natural enemies of spider mites including webmaking Tetranychus species. N. womersleyi has a wide national distribution from north of Hokkaido to south of Okinawa. Among phytoseiid species in Japan, N. womersleyi has been the subject of most research (Amano, 1999).

On the other hand, $N$. californicus has until recently received little attention in Japan, and only information available in the textbook was on its worldwide distribution of Europe, Africa, North and South Americas. In 1963, 1 female and 4 male adults were found attacking a population of Phytonemus pallidus (Banks) in Tokyo (Ehara, 1964), but after this first report, no publications referred to its ecology for decades in Japan. One of the present authors (H.A.) started a nation-wide collection of phytoseiid mites in 1983 and 45 adult females of $N$. californicus were sampled in the 1980's. The number sharply increased to 1437 females in the 1990's and it is continuing to increase at present (Amano, unpublished data). Both the number and geographical distribution of $N$. californicus have been increasing in recent years. N. californicus used to be found in the Kanto area in central Japan. Then it expanded to southwest and has now reached Hiroshima and Yamaguchi prefectures.

Most collections of $N$. californicus were from pear trees and underground weeds in the

*Corresponding author 
orchards in which conventional pest management with chemicals was conducted. $N$. womersleyi was usually the only survivor under these conditions and it occupied a dominant position among phytoseiid fauna throughout Japan. In the 1990's, however, N. californicus replaced the position of $N$. womersleyi in many orchards (Amano, 2001). At present, the reasons for this replacement are speculative.

In this study, we tested the hypothesis that the species replacement was due to a change in pesticides used in orchards combined with a differential susceptibility of the two species to one or more of the new pesticides. Besides native populations collected for this study, commercial product of $N$. californicus (product name Spical ${ }^{\circledR}$ ) for use of biocontrol was also included here to test possible future impact of an introduced strain.

\section{MATERIALS AND METHODS}

\section{Mite populations}

Nine populations of phytoseiid mites were selected for this study (Table 1). One of the $N$. californicus populations, Spical ${ }^{\circledR}$, was kindly provided by Arysta LifeScience Co. in March 2000. No information on the origin of population was available. In Futtsu (Chiba pref.) and Nagano (Nagano pref.), populations of the two species co-occurred on the same plants. After collection, each population was maintained in the laboratory with T. urticae Koch (green-form) as prey on excised kidney bean leaves.

\section{Pesticides}

Twenty-two pesticides, mostly acaricides, were used in the study with their experimental dilutions ranging from 500 to 2000 (Table 2). These chemicals are commonly used in deciduous fruit tree orchards in Japan. Pesticides that have an extensive history of use such as dicofol, as well as products including milbemectin (W.P.), milbemectin (E.C.), pyridaben, fenpyroximate, bifenthrin, tebufenpyrad, halfenprox and acrinathrin which have entered the market since 1990 have been tested in this experiment. Among the 22 pesticides, six are insecticides (five of which are synthetic pyrethroids) and the rests are acaricides.

\section{Bioassay}

In the study, the susceptibility of mites was tested by the method of Helle and Overmeer

Table 1. Collection record of 4 populations of $N$. californicus and 5 populations of $N$. womersleyi

\begin{tabular}{llllc}
\hline & Population & Site of collection & Collected plants & Date of collection \\
\hline \multirow{4}{*}{ N. californicus } & Ichihara & Chiba, Ichihara & pear & 1995.8 \\
& Futtsu & Chiba, Futtsu & kudzu vine & 2000.5 \\
& Nagano & Nagano, Matsukawa & pear & 2000.9 \\
& $*$ Spical ${ }^{\circledR}$ & unknown & unknown & unknown (2000.3) \\
\hline \multirow{4}{*}{ N. womersleyi } & Matsudo & Chiba, Matsudo & kudzu vine & 1998.7 \\
& Futtsu & Chiba, Futtsu & kudzu vine & 2000.5 \\
& Nagano & Nagano, Matsukawa & pear & 2000.9 \\
& Iwate & Iwate, Morioka & apple & 1999.1 \\
& Taiwan & Taiwan, Nantou & tea & 1999.12 \\
\hline
\end{tabular}

\footnotetext{
* Commercial product of Arysta Lifescience Corporation (obtained in March 2000).
} 
Table 2. Pesticides used for susceptibility test

\begin{tabular}{lccc}
\hline \multicolumn{1}{c}{ Pesticide } & Active component (\%) & Formulation* & Dilution $(\times)$ \\
\hline Insecticide & & & \\
acrinathrin & 3 & W.P. & 1,000 \\
halfenprox & 5 & M.C. & 1,000 \\
bifenthrin & 2 & W.P. & 1,000 \\
fluvalinate & 20 & W.P. & 2,000 \\
fenpropathrin & 10 & W.P. & 1,000 \\
chlorfenapyr & 10 & F. & 2,000 \\
Acaricide & & & \\
acequinocyl & 15 & F. & 1,000 \\
propargite & 30 & W.P. & 750 \\
etoxazole & 10 & F. & 2,000 \\
hexythiazox & 10 & W.P. & 2,000 \\
tebufenpyrad & 10 & W.P. & 1,000 \\
pyridaben & 20 & W.P. & 2,000 \\
fenpyroximate & 5 & F. & 1,000 \\
milbemectin & 2 & W.P. & 2,000 \\
milbemectin & 1 & E.C. & 1,000 \\
tetradifon & 18 & W.P. & 500 \\
fenbutatin oxide & 25 & W.P. & 1,000 \\
fenbutatin oxide & 45 & F. & 2,000 \\
amitraz & 20 & E.C. & 1,000 \\
phenisobromolate & 45 & E.C. & 1,500 \\
dicofol & 40 & E.C. & 1,500 \\
bifenazate & 20 & F. & 1,000 \\
\hline
\end{tabular}

*F.: flowable, W.P.: wettable powder, M.C.: microcapsule, E.C.: emulsifiable concentrate.

(1985) in which the dorsal side of the adult female was placed on a slide glass with doublesided sticky tape and the slide glass was dipped into each chemical solution for 5 seconds. The mite was then dried in the room for 15 minutes during which extra solution of pesticides on the mite body was wiped out with a tissue. The mite on the slide glass was placed in an incubator controlled at $25 \pm 1{ }^{\circ} \mathrm{C}$ and high RH. After 24 hours, the legs were gently touched with a fine brush. If the mite showed no reaction, it was judged as dead. Control mites were treated in the same way except that they were dipped in distilled water. Mortality of the control mites was used to correct mortality of the pesticide-treated mites using Abbott's formula (Abbott, 1925). The original mortality data in the experimental results showed some difficulties in analysis using a statistical method so the pesticide effects on predacious mites were evaluated by the IOBC toxicity category (Hassan, 1994) with which chemicals were categorized as harmless (1: mortality $<30 \%)$, slightly harmful $(2: 30-79 \%)$, moderately harmful (3: 80-99\%) and harmful (4: >99\%).

\section{RESULTS}

Nine populations of phytoseiid mites, representing two species, were exposed to 22 
pesticides. The corrected mortalities of each of these populations ranged from zero to 100 percent depending on the pesticide (Table 3). The IOBC index of the pesticides, over the nine populations, ranged from 1 (harmless) to 4 (harmful). Amitraz showed no variation in toxicity impacts across different species or populations. However, acrinathrin demonstrated a wide variance in toxicity depending on population. Four pesticides (propargite, hexythiazox, chlorfenapyr and fenbutatin) were 'harmless' to each of the populations (Table 3). On the other hand, milbemectin (W.P.) and amitraz had 'harmful' or 'moderately harmful' influences on all populations of the two species.

Based on the IOBC categories, no clear differences were detected in the general trend of pesticide susceptibility between $N$. californicus and $N$. womersleyi. However, when the effects of the pesticides were compared between N. californicus and N. womersleyi, in populations found at the same sites (Futtsu and Nagano), some differences were observed (Table 3). At Futtsu, both N. californicus and N. womersleyi suffered high mortalities after exposure to the 3 out of 5 pyrethroids (Five underlined compounds are synthetic pyrethroids in the table), compared to the Nagano population. Mites from Futtsu also showed interspecific differences in mortality to the pyrethroids, but the direction of tolerance depended on the kind of pyrethroids.

Table 3. Corrected mortality and IOBC toxicity category of $N$. californicus and $N$. womersleyi after 24 hours of pesticide application.

\begin{tabular}{|c|c|c|c|c|c|c|c|c|c|}
\hline \multirow{3}{*}{ Pesticide } & \multicolumn{9}{|c|}{$\%$ corrected mortality (IOBC category) No. of mites tested } \\
\hline & \multicolumn{4}{|c|}{ N. californicus } & \multicolumn{5}{|c|}{ N. womersleyi } \\
\hline & Ichihara & Futtsu & Nagano & Spical & Iatsudo & Futtsu & Nagano & Iwate & Taiwan \\
\hline cequinocyl & $72.4(2) 30$ & $67.0(2) 28$ & $22.2(1) 42$ & $35.8(2) 32$ & $67.2(2) 33$ & $52.8(2) 36$ & $46.2(2) 34$ & $42.3(2) 33$ & 74.9 (2) 34 \\
\hline propargite & 2 (1) 30 & 0.9 (1) 30 & 1) 30 & (1) 30 & 3 (1) 30 & $20.3(1) 20$ & $15.9(1) 29$ & $15.4(1) 30$ & $8(1) 31$ \\
\hline etoxazole & $35.2(2) 32$ & $8.0(1) 39$ & $10.4(1) 40$ & $65.7(2) 33$ & $86.9(3) 33$ & $22.1(1) 30$ & $60.0(2) 33$ & 67.9 (2) 33 & $25.6(1) 33$ \\
\hline$\underline{\text { acrinathrin }}$ & (4) 30 & $100(4) 30$ & 21.0 (1) 28 & 30 & 30 & 00 (4) 30 & 45.8 (2) 30 & $96.5(3) 30$ & ) 30 \\
\hline$\underline{\text { halfenprox }}$ & 8.9 (1) 33 & 15.8 (1) 28 & 6.8 (1) 26 & 15.9 (1) 33 & 72.9 (2) 32 & $23.6(1) 32$ & 10.7 (1) 33 & $58.3(2) 30$ & 11.5 (1) 27 \\
\hline$\underline{\text { bifenthrin }}$ & 0 (4) 30 & 100 (4) 30 & 69.4 (2) 31 & 30 & 30 & 96.5 (3) 30 & 30 & $100(4) 30$ & 21.7 (1) 30 \\
\hline$\underline{\text { fluvalinate }}$ & 49.9 (2) 31 & $62.4(2) 30$ & $36.0(2) 28$ & 65.7 (2) 30 & $85.6(3) 30$ & 92.9 (3) 30 & 15.3 (1) 30 & $59.9(2) 29$ & $0.3(1) 30$ \\
\hline fenpropathrin & $100(4) 30$ & $96.6(3) 30$ & 47.3 (2) 30 & $96.6(3) 30$ & $100(4) 30$ & $100(4) 30$ & $49.2(2) 30$ & $100(4) 30$ & 13.0 (1) 27 \\
\hline hexythiazox & $0(1) 30$ & 4.1 (1) 31 & $0(1) 30$ & $0(1) 28$ & 16.9 (1) 30 & 18.5 (1) 30 & $5.1(1) 30$ & $0(1) 30$ & 3.9 (1) 30 \\
\hline tebuf & 100 (4) 30 & $96.6(3) 30$ & 92.7 (3) 29 & $93.1(3) 30$ & $65.1(2) 31$ & $72.6(2) 31$ & 18.7 (1) 30 & $68.3(2) 30$ & 14.6 (1) 30 \\
\hline pyridaben & 72.4 (2) 30 & $28.2(1) 30$ & $40.3(2) 30$ & $76.0(2) 30$ & 81.9 (3) 30 & $75.2(2) 30$ & 83.1 (3) 30 & 85.9 (3) 30 & $68.0(2) 30$ \\
\hline chlorfenapyr & 14.1 (1) 35 & 7.1 (1) 32 & 1.7 (1) 30 & 2.9 (1) 36 & 4.0 (1) 35 & 27.1 (1) 35 & 4.0 (1) 36 & 0 (1) 35 & $0(1) 34$ \\
\hline fenpyroximate & $97.0(3) 34$ & 96.9 (3) 33 & $96.2(3) 28$ & $97.1(3) 35$ & $97.0(3) 36$ & 83.4 (3) 32 & 78.4 (2) 33 & $82.4(3) 30$ & 44.6 (2) 27 \\
\hline milbemectin (W.P.) & $30.9(2) 30$ & $96.6(3) 30$ & $100(4) 30$ & 89.7 (3) 30 & $88.8(3) 29$ & $100(4) 30$ & $93.2(3) 30$ & $96.5(3) 30$ & 80.9 (3) 28 \\
\hline in (E.C.) & 70.9 (2) 32 & 24.0 (1) 27 & 62.6 (2) 31 & 53.6 (2) 31 & 79.7 (2) 32 & 81.8 (3) 35 & 81.5 (3) 33 & 86.4 (3) 31 & $60.0(2) 32$ \\
\hline tetradifon & $37.8(2) 30$ & $38.5(2) 30$ & 29.8 (1) 30 & $24.6(1) 30$ & $85.6(3) 30$ & $54.0(2) 30$ & 28.9 (1) 30 & $54.2(2) 30$ & $50.2(2) 30$ \\
\hline fenbutatin oxide (W.P.) & $52.5(2) 24$ & 35.5 (2) 35 & $50.6(2) 32$ & 40.5 (2) 38 & $54.6(2) 31$ & $65.6(2) 34$ & 42.3 (2) 37 & $67.9(2) 33$ & 54.7 (2) 33 \\
\hline fenbutatin oxide (F.) & $0(1) 30$ & 1.5 (1) 25 & 15.7 (1) 35 & $0(1) 23$ & $20.3(1) 34$ & 0 (1) 16 & $11.1(1) 32$ & 4.8 (1) 30 & $0(1) 34$ \\
\hline amitraz & $100(4) 30$ & 100 (4) 30 & $96.5(3) 30$ & 89.7 (3) 30 & 100 (4) 30 & $100(4) 30$ & 100 (4) 31 & $100(4) 30$ & 100 (4) 30 \\
\hline phenisol & $56.2(2) 26$ & 48.7 (2) 26 & $37.6(2) 28$ & $5.4(1) 25$ & $71.1(2) 30$ & 92.9 (3) 30 & $72.9(2) 30$ & $67.2(2) 29$ & $44.8(2) 29$ \\
\hline dicofol & $55.6(2) 21$ & 48.7 (2) 26 & $59.2(2) 31$ & 43.5 (2) 20 & 74.7 (2) 30 & $82.3(3) 30$ & 86.0 (3) 29 & $50.6(2) 30$ & 59.5 (2) 29 \\
\hline bifenazate & 23.1 (1) 31 & $31.6(2) 33$ & 8.7 (1) 30 & 32.6 (2) 32 & 49.4 (2) 30 & 13.1 (1) 22 & 0 (1) 30 & 33.0 (2) 30 & $14.6(1)$ \\
\hline
\end{tabular}

Underlined pesticides are synthetic pyrethroids. 


\section{DISCUSSION}

Was the species replacement from $N$. womersleyi to $N$. californicus caused by differential susceptibility to pesticides commonly used in orchards? The present results suggest that differential susceptibility alone cannot account for this replacement. For N. womersleyi, four pesticides (chlorfenapyr, bifenazate, acequinocyl and etoxazole) were previously shown to be relatively harmless and one (milbemectin) was shown to be harmful (Kim and Seo, 2001). Our results generally agree with Kim and Seo (2001). On the other hand, our results do not agree with the finding by Sasaki and Sato (1997) that tebufenpyrad was quite harmful to $N$. womersleyi. Inter-population variability must have played some role in these differences.

The IOBC index showed some differences between different formulations of fenbutatin oxide and milbemectin. A formulation-dependent susceptibility difference was also shown by Mochizuki (1997) in the effect of permethrin on N. womersleyi: an emulsifiable concentrate was more lethal than a wettable powder.

The Nagano population of $N$. californicus and the Taiwan population of $N$. womersleyi were relatively tolerant to pesticides (Table 3). In the Nagano area, N. californicus replaced $N$. womersleyi in many fruit orchards within several years (Wakabayashi, 2000). Therefore, an analysis of the pesticide tolerance of these populations may provide some clues to the cause of the species replacement. The spray calendar (made by prefectural authorities) for pear orchards in Nagano prefecture strongly suggests that during the period of 1982-2001 farmers used 17 of the pesticides listed in Table 2 (all but acrinathrin, halfenprox, fenpropathrin, amitraz and bifenazate). The relatively high tolerance of the Nagano populations to pesticides shown in the present study might be due to their long-term exposure to these chemicals.

Our collection records of Japanese phytoseiid mites suggest that the numbers and geographical distribution of $N$. californicus rapidly increased around 1995. If pesticides had a significant role in these increases, special attention should be paid to those chemicals that were first listed in the calendar spraying schedule (and thus widely used as a commercial product). Milbemectin (W.P.), milbemectin (E.C.), pyridaben, fenpyroximate, bifenthrin, tebufenpyrad, halfenprox and acrinathrin are listed for frequent use during those periods. The IOBC values for $N$. californicus and $N$. womersleyi populations for most of these pesticides were about the same (Table 3). Based on these values, milbemectin (E.C.) and pyridaben showed the biggest differences between the two species and both were less lethal to $N$. californicus than to $N$. womersleyi. Thus these pesticides might have been involved in the species shift to $N$. californicus. However, more data is needed to confirm this. Furthermore, the effect of the W.P. formulation of milbemectin was not very different between the two species.

Using milbemectin or pyridaben as examples, species sensitivity indicated large differences between chemicals, but we were unable to present any decisive results showing that difference in chemical toxicity was a key factor for rapid species replacement in field populations. The current research showed an importance of toxicity data when we try to understand field population dynamics of predatory mites, but our approach was limited to the 
acute mortality of adult females. Further analysis is now needed of chemical effects on other developmental stages as well as on the sub-lethal damage to mites.

\section{REFERENCES}

Abbott, W. S. (1925) A method of computing the effectiveness of an insecticide. Journal of Economic Entomology, 18: $265-276$.

Amano, H. (1999) Recent advances in studies on domestic predacious phytoseiid mites in Japan. Journal of the Acarological Society of Japan, 8: 1-7. (in Japanese with English summary)

Amano, H. (2001) Species structure and abundance of invertebrate natural enemies in sustainable agroecosystems. In: Structure and Function in Agroecosystem Design and Management (M. Shiomi and H. Koizumi eds.). CRC Press, New York, pp. 167-182.

Ehara, S. (1964) Some mites of the families Phytoseiidae and Blattisocidae from Japan (Acarina: Mesostigmata). Journal of the Faculty of Science, Hokkaido University Series 6 Zoology, 15: 378-394.

Hassan, S. A. (1994) Activities of the IOBC/WRPS working group on pesticide and beneficial organisms. In: Pesticides and Beneficial Organisms (H. Vogt ed.). Bulletin of IOBC/WRPS, 17: 1-5.

Helle, W. and W. P. J. Overmeer (1985) Toxicological test methods. In: Spider Mites $1 A$ (W. Helle and M. W. Sabelis eds.). Elsevier, Amsterdam, pp. 391-395.

Kim, S. S. and S. G. Seo (2001) Relative toxicity of some acaricides to the predatory mite, Amblyseius womersleyi and the twospotted spider mite, Tetranychus urticae (Acari: Phytoseiidae, Tetranychidae). Applied Entomology and Zoology, 36: 509-514.

Mochizuki, M. (1997) Permethrin resistance and stability in the predatory mite, Amblyseius womersleyi Schicha (Acari: Phytoseiidae). Japanese Journal of Applied Entomology and Zoology 41: 1-5. (in Japanese with English summary)

Sasaki, M. and R. Sato (1997) Susceptibility of Amblyseius womersleyi Schicha (Acari: Phytoseiidae) to some insecticides and acaricides in Fukushima prefecture. Annual Report of the Society of Plant Protection of North Japan, 48: 192-195. (in Japanese)

Wakabayashi, H. (2000) Utilization of predacious phytoseiid mites in control of spider mites on fruit trees in Nagano prefecture. Japan Agricultural Technology, 44(5): 113-119. (in Japanese)

\section{摘要}

日本の慣行防除果樹園で優占するミヤコカブリダニとケナガカブリダニの薬剤感受性

天野洋・石井由紀・小堀陽一（千葉大・園芸・応動昆）

わが国の慣行防除下にある果樹園では，近年，優占するカブリダニ種が変わってきた，そ の原因を探る過程で,「使用された化学薬剤の変遷とそれらへの薬剤感受性の違いがカブリダ 二優占種の変化をもたらした」との仮説をたてた，そこで，従来からの優占種であったケナ ガカブリダニと近年急速に個体数を増やしているミヤコカブリダニの, 慣行的に使用されて きた薬剤 22 種（殺虫剤 6 種，殺ダニ剤 16 種）に対する薬剤感受性を検定した。 その結果, 近年の急速な優占種変遷を, 使用された薬剤に関連する理由のみで説明する事は困難と考兄 られた。ただ，本結論を断定するにはより詳細な調査が必要と考兄られた。 